\title{
An economic analysis of processing of sugarcane in Beed district
}

R.R. WAGHMODE, K.V. DESHMUKH AND R.A. KOLAMBKAR

Received : 02.05.2014; Revised : 01.08.2014; Accepted : $14.08 .2014 \bullet$

\begin{abstract}
Study revealed that in regards to processing unit of sugarcane that production per annum worked out to be Rs.16667.5 lakh of this share of variable and fixed cost estimated at 82.63 and 14.81 per cent. Break-even volume was worked out to be 24.75 lakh tonnes. The per cent of break even volume of installed capacity and actual quantities of sugarcane crushed was estimated at 170.68 and 247.25 per cent, respectively. The capital investment of distillery was worked out to be Rs.2901.6 lakh. Net returns realized by distillery in year 2011-12 estimated was 59.31 lakh, the input-output ratio for the year estimated was 1.10 .
\end{abstract}

KEY WORDS : Sugarcane, Processing, Distillery, Break even volume

How to cite this paper : Waghmode, R.R., Deshmukh, K.V. and Kolambkar, R.A. (2014). An economic analysis of processing of sugarcane in Beed district. Internat. J. Com. \& Bus. Manage, 7(2) : 260-264.

\section{MEMBERS OF THE RESEARCH FORUM}

Correspondence to:

R.A. KOLAMBKAR, Department of Agricultural Economics, College of Agriculture, Vasantrao Naik Marathwada Krishi Vidyapeeth, PARBHANI (M.S.) INDIA

Email: kolambkar.rachana14@gmail.com

Authors' affiliations:

R.R. WAGHMODE AND K.V. DESHMUKH, Department of Agricultural Economics, College of Agriculture, Vasantrao Naik Marathwada Krishi Vidyapeeth, PARBHANI (M.S.) INDIA

Email: rupaliwaghmode88@gmail.com, deshmukh_kv@rediffmail.com 